Case Report

\title{
Thyroid, Renal, and Breast Carcinomas, Chondrosarcoma, Colon Adenomas, and Ganglioneuroma: A New Cancer Syndrome, FAP, or Just Coincidence
}

\author{
Ihab Shafek Atta $^{1}$ and Fahd Nasser AlQahtani ${ }^{2}$ \\ ${ }^{1}$ Department of Pathology, Faculty of Medicine, Al-Azhar University, Assiut Branch, Assiut 71524, Egypt \\ ${ }^{2}$ Department of Radiology, Faculty of Medicine, Al-Baha University, Saudi Arabia \\ Correspondence should be addressed to Ihab Shafek Atta; attaihab@yahoo.com
}

Received 30 November 2015; Revised 8 February 2016; Accepted 18 February 2016

Academic Editor: Mark E. Shaffrey

Copyright (C) 2016 I. S. Atta and F. N. AlQahtani. This is an open access article distributed under the Creative Commons Attribution License, which permits unrestricted use, distribution, and reproduction in any medium, provided the original work is properly cited.

\begin{abstract}
We are presenting a case associated with papillary thyroid carcinoma, renal cell carcinoma, invasive mammary carcinoma, chondrosarcoma, benign ganglioneuroma, and numerous colon adenomas. The patient had a family history of colon cancer, kidney and bladder cancers, lung cancer, thyroid cancer, leukemia, and throat and mouth cancers. She was diagnosed with colonic villous adenoma at the age of 41 followed by thyroid, renal, and breast cancers and chondrosarcoma at the ages of 48, 64, 71, and 74, respectively. Additionally, we included a table with the most common familial cancer syndromes with one or more benign or malignant tumors diagnosed in our case, namely, FAP, HNPCC, Cowden, Peutz-Jeghers, renal cancer, tuberous sclerosis, VHL, breast/other, breast/ovarian, Carney, Werner's, Bloom, Li-Fraumeni, xeroderma pigmentosum, ataxiatelangiectasia, osteochondromatosis, retinoblastoma, and MEN2A.
\end{abstract}

\section{Introduction}

A cancer diagnosed at young age, multifocal or bilateral in paired organs, more than one primary unrelated cancer, family history of cancer, or congenital anomalies will make the diagnosis of family cancers syndromes a high possibility [1]. Familial adenomatous polyposis (FAP) is a syndrome with mutations in APC gene on 5q21-q22. Diagnosis of FAP is suspected clinically in the presence of hundreds of colorectal polyps running in certain families but mutational analysis study is the golden test for diagnosis. Colon cancer, follicular cancer, papillary thyroid cancer, gastric cancer, and medulloblastomas (Turcot syndrome) are the most common malignant tumors $[2,3]$. Associated benign lesions are colonic, gastric, and duodenal polyps $[4,5]$. Hereditary Nonpolyposis Colon Cancer (HNPCC) is another syndrome with reported mutations in the mismatch repair gene (MMR) complexes that include several mutations as hMLH1 at 3p21.3, hMSH2 at 2p22-p21, hPMS1 at 2q31-q33, hPMS2 at 7p22, and hMSH6 at 2 p16 [6]. Diagnosis depends on a family pedigree with colon cancer diagnosed before the age of 50 with no familial adenomatous polyposis detected [6]. Associated malignant neoplasms are colorectal, endometrial, ovarian, and transitional cell cancers of the urinary system, gastric cancer, small bowel cancer, pancreas cancer, hepatobiliary carcinoma, sebaceous carcinoma, glioblastoma multiforme, and breast cancer [2, 7]. Associated benign neoplasms are colonic adenomas, keratoacanthomas, sebaceous adenomas, and epitheliomas. Cowden syndrome is reported with mutations in PTEN gene at $10 \mathrm{q} 23$ [8-10]. Clinical diagnosis is based on mucocutaneous lesions, intestinal hamartomas, craniomegaly, coarse, dark hair, rapid overgrowth of breasts, and cerebellar glial mass leading to altered gait and seizures (Lhermitte-Duclos disease). Associated malignant tumors are breast, thyroid, colon, kidney, ovary, endometrium, and lung carcinomas, melanoma, Merkel cell skin cancer, and retinal glioma. Associated benign lesions are skin verruci of the face and limbs, hyperkeratotic papules of the gingiva and buccal mucosa, facial trichilemmomas, oral mucosal fibromas, hyperkeratosis of hand and foot, hamartomatous polyps of stomach, small 
bowel, and colon, lipomas, cerebellar gangliocytomatosis, thyroid adenomas, and hemangiomas [11]. Familial renal cell carcinoma (RCC) is reported with mutations in MET protooncogene at 7q31.1-34 in the papillary RCC type [12]. The gene for the nonpapillary/clear cell type located at 3p14.2 has not yet been cloned which is thought to be distinct from the gene of von Hippel-Lindau [13]. Diagnosis is mainly by finding multifocal or bilateral papillary RCC without family history or a single tumor with family history of papillary RCC $[14,15]$. Associated malignant neoplasms are renal, stomach, rectal, breast, lung, pancreatic, and bile duct cancers [14, 15].

We are presenting, for the first time, a case associated with metastatic papillary thyroid carcinoma, renal cell carcinoma, invasive breast carcinoma with intraductal component, chondrosarcoma, benign ganglioneuroma, and numerous colon adenomas from the age of 41 to the age of 74 .

\section{Case Report}

2.1. Personal History. The patient is a 76-year-old white female with past medical history significant for multiple cancers and benign tumors, hypertension, gastroesophageal reflux disease, and osteoporosis. The patient's history is significant for allergy to penicillin which causes anaphylaxis and allergy to epinephrine and oxycodone. She is nonsmoker and has one alcoholic beverage per day. She is retired and has two children. The patient is on Synthroid, Cardura, Monopril, Zocor, Prilosec, Boniva, Darvocet-N, and Colace medication.

2.2. Papillary Thyroid Carcinoma. The patient had a past medical history significant for right thyroid lobectomy with modified radical ipsilateral neck dissection for papillary thyroid cancer with metastatic lymph node 28 years ago. Last year, a fine-needle aspiration and subsequent biopsy from a hypoechoic lesion in the right thyroid fossa were positive for metastatic papillary thyroid carcinoma in lymph node (Figure 1(a)) and the patient underwent reexcision followed by radioactive iodine therapy.

2.3. Renal Cell Carcinoma. The patient was diagnosed with moderately differentiated, $8.3 \mathrm{~cm}$, Fuhrman grade $2 / 4$ renal cell carcinoma with invasion into the perinephric fat 16 years ago requiring left nephrectomy (Figure 1(b)).

2.4. Mammary Carcinoma. Four years ago, the patient underwent left breast core biopsy that revealed ER/PR positive ductal carcinoma in situ (DCIS) of low-grade, cribriform pattern with microcalcification (Figure 1(c)). A ductal epithelial hyperplasia and benign papilloma were also noted. A lumpectomy specimen revealed a microscopic focus of invasive ductal carcinoma (IDC), grade I, with maximum dimension of $2 \mathrm{~mm}$ (Figure 1(d)) associated with multiple foci of DCIS. The IDC is ER positive and PR negative. The HER2/neu is not amplified by FISH assay. Sentinel lymph node biopsies from two lymph nodes were negative for tumor deposits.

2.5. Colonic Polyps and Ganglioneuroma. A large villous adenoma with focus of adenocarcinoma in situ in anterior rectal wall was excised 34 years ago, adenomatous transverse colonic adenomatous polyp and rectum hyperplastic polyp were excised 26 years ago, and a tubular adenomatous polyp in transverse colon was diagnosed 3 years ago (Figure 1(e)). Two years ago a ganglioneuroma was detected in a biopsy from paratracheal mass (Figure 1(f)).

2.6. Physical Examination. Physical examination and review of systems demonstrate adult female in no acute distress; she is afebrile with normal vital signs and clear oropharynx. There is no cervical adenopathy, neither carotid bruit nor jugular venous distention. Trachea is midline and lung fields are clear to auscultation bilaterally with good airflow entry.

2.7. Chondrosarcoma. The chondrosarcoma will be discussed here with some detail because this is the presentation of the patient prior to writing this report. The patient first noted a mass on her right chest wall last year around the time of her workup for recurrent thyroid carcinoma. Initially, the patient was asymptomatic; however, as the mass enlarged, the patient began to develop chest wall discomfort. Physical exam was significant for a palpable, fixed, nontender, $5 \mathrm{~cm}$ mass at the costochondral joint along the right 4th rib. The skin as well as soft tissue around the mass was freely movable. No overlying skin changes were noted. CT scan of the chest was significant for a $5.3 \times 2.9 \mathrm{~cm}$ mass at the costochondral junction of the right 4 th rib. No mediastinal lymphadenopathy or pulmonary masses were noted. A nuclear medicine bone scan revealed increased radiotracer activity along the anterior 4th rib in correlation with the findings on the CT scan. There was also increased uptake along the left 6th rib with no associated CT abnormality. Fine-needle aspiration of the mass was negative. Core needle biopsy revealed low-grade chondrosarcoma with positive ki-67 in malignant chondrocytes. The patient underwent operative excision of her chondrosarcoma with chest wall reconstruction. Postoperatively, the patient developed onset of dyspnea and hypotension and hematocrit drop from $34 \%$ to $20 \%$ and a chest X-ray revealed a right pleural fluid collection. Bleeding vessel was ligated and the hemothorax was evacuated along the breast tissue flap. Pathologically a low-grade chondrosarcoma of $6.5 \mathrm{~cm}$ with free soft tissue and bony margins was the diagnosis (Figure $1(\mathrm{~g})$ ).

2.8. Family History. Colon cancer in sibling was diagnosed at the age of 58, patient's mother died of colon cancer at the age of 89 , and two of the siblings of the patient's mother and their father were all diagnosed in their eighth or ninth decades with colon cancer. Kidney and bladder cancers were diagnosed in maternal first cousin and lung cancer was diagnosed in other brother, two maternal first cousins, and a maternal aunt. A first cousin was diagnosed with thyroid cancer. The patient's father died of leukemia at the age of 60, and each of his two brothers had throat and mouth cancers. One of the patient's brothers died of colon cancer at the age of 60 , and one brother has been diagnosed with lung cancer. The patient was born in UK and there is no Jewish ancestry (family pedigree, Figure 2). 


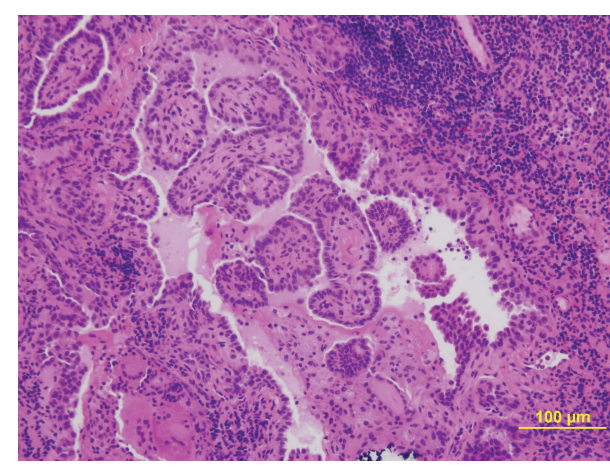

(a)

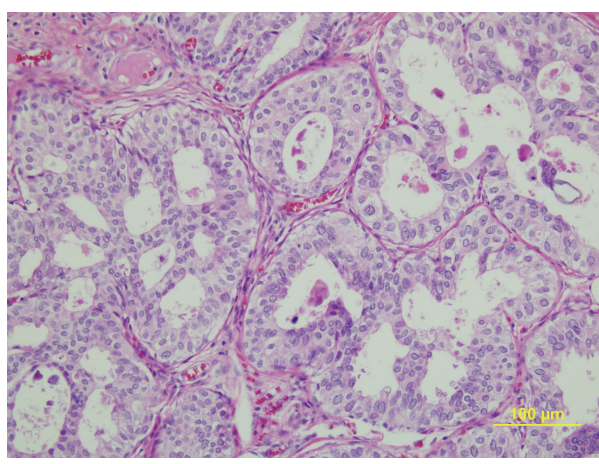

(c)

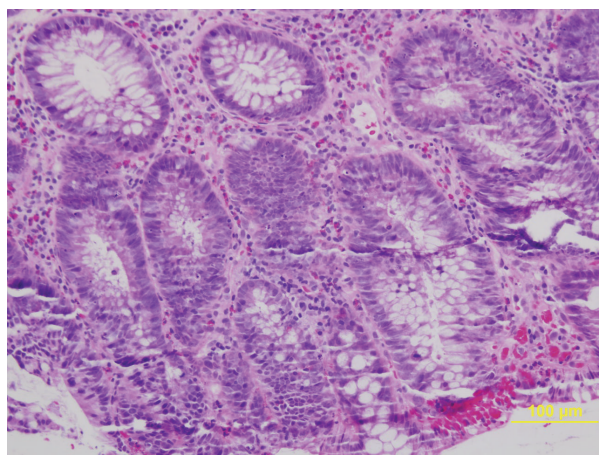

(e)

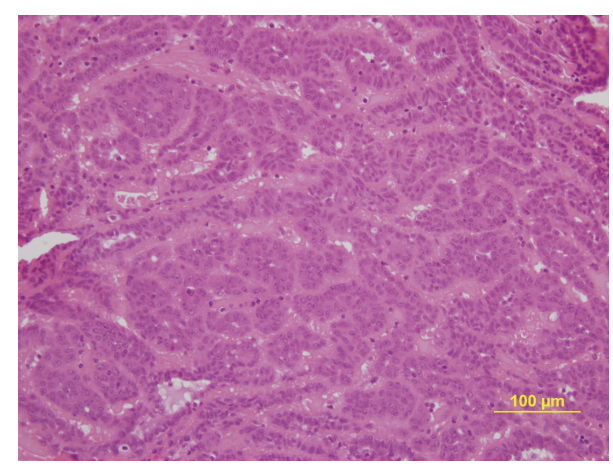

(b)

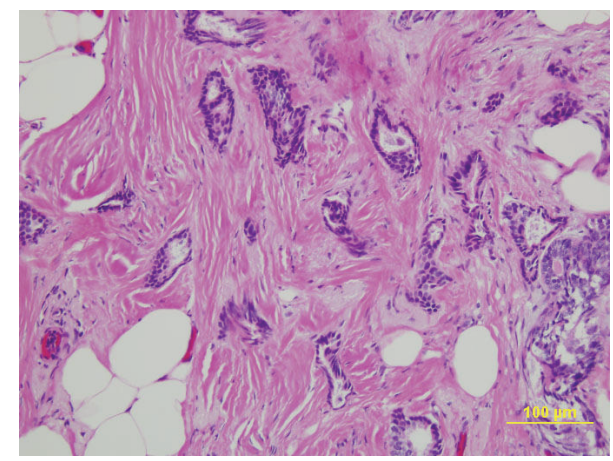

(d)

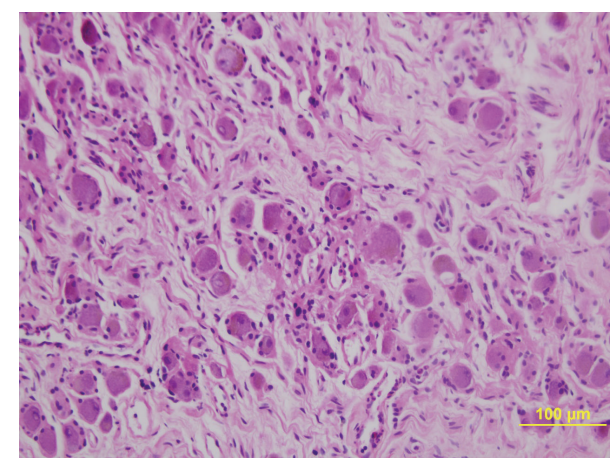

(f)

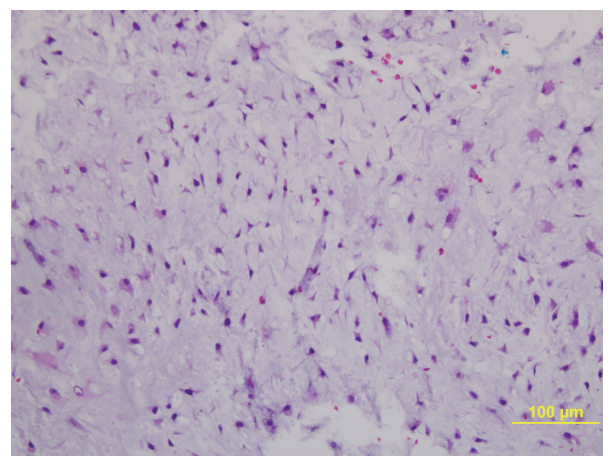

(g)

FIGURE 1: Malignant and benign lesions in the case. (a) Lymph node: metastatic papillary thyroid carcinoma in lymph node (H\&E stain, $\times 200$ original magnification, bar $=100$ micrometers). (b) Kidney: renal cell carcinoma (H\&E stain, $\times 200$ original magnification, bar $=100$ micrometers). (c) Breast: ductal carcinoma in situ (H\&E stain, $\times 200$ original magnification, bar $=100$ micrometers). (d) Breast: invasive ductal carcinoma (H\&E stain, $\times 200$ original magnification, bar $=100$ micrometers). (e) Colon: tubular adenomatous polyp (H\&E stain, $\times 200$ original magnification, bar $=100$ micrometers). (f) Paratrachea: ganglioneuroma (H\&E stain, $\times 200$ original magnification, bar $=100$ micrometers). (g) Chest wall: chondrosarcoma (H\&E stain, $\times 200$ original magnification, bar $=100$ micrometers). 
TABLE 1: Most common reported cancer syndromes with one or more components from the presented case.

\begin{tabular}{|c|c|c|c|c|c|c|c|}
\hline Syndrome & Inheritance & $\begin{array}{c}\text { Thyroid } \\
\text { carcinoma }\end{array}$ & $\begin{array}{c}\text { Renal } \\
\text { carcinoma }\end{array}$ & $\begin{array}{c}\text { Breast } \\
\text { carcinoma }\end{array}$ & Chondrosarcoma & $\begin{array}{l}\text { Colonic } \\
\text { adenomas }\end{array}$ & Ganglioneuroma \\
\hline Adenomatous polyposis & Dominant & $\mathrm{X}$ & & & & $\mathrm{X}$ & \\
\hline Colon (HNPCC) & Dominant & & $\mathrm{X}$ & $\mathrm{X}$ & & $\mathrm{X}$ & \\
\hline Cowden & Dominant & $\mathrm{X}$ & $\mathrm{X}$ & $\mathrm{X}$ & & & \\
\hline Peutz-Jeghers & Dominant & & & $\mathrm{X}$ & & $\mathrm{X}$ & \\
\hline Renal cancer & Dominant & & $\mathrm{X}$ & $\mathrm{X}$ & & & \\
\hline Tuberous sclerosis & Dominant & $\mathrm{X}$ & $\mathrm{X}$ & & & & \\
\hline VHL & Dominant & & $\mathrm{X}$ & & & & \\
\hline Breast/other & Dominant & $\mathrm{X}$ & $\mathrm{X}$ & $\mathrm{X}$ & $\mathrm{X}$ & & \\
\hline Breast/ovarian & Dominant & & & $\mathrm{X}$ & & & \\
\hline Carney & Dominant & $\mathrm{X}$ & & & & & \\
\hline Werner's & Recessive & $\mathrm{X}$ & & $\mathrm{X}$ & & & \\
\hline Bloom & Recessive & & & $\mathrm{X}$ & & & \\
\hline Li-Fraumeni & Dominant & & & $\mathrm{X}$ & & & \\
\hline Xeroderma pigmentosum & Dominant & & & $\mathrm{X}$ & & & \\
\hline Ataxia-telangiectasia & Recessive & & & $\mathrm{X}$ & & & \\
\hline Osteochondromatosis & Dominant & & & & $\mathrm{X}$ & & \\
\hline Retinoblastoma & Dominant & & & & $\mathrm{X}$ & & \\
\hline MEN2A & Dominant & & & & & & $\mathrm{X}$ \\
\hline
\end{tabular}

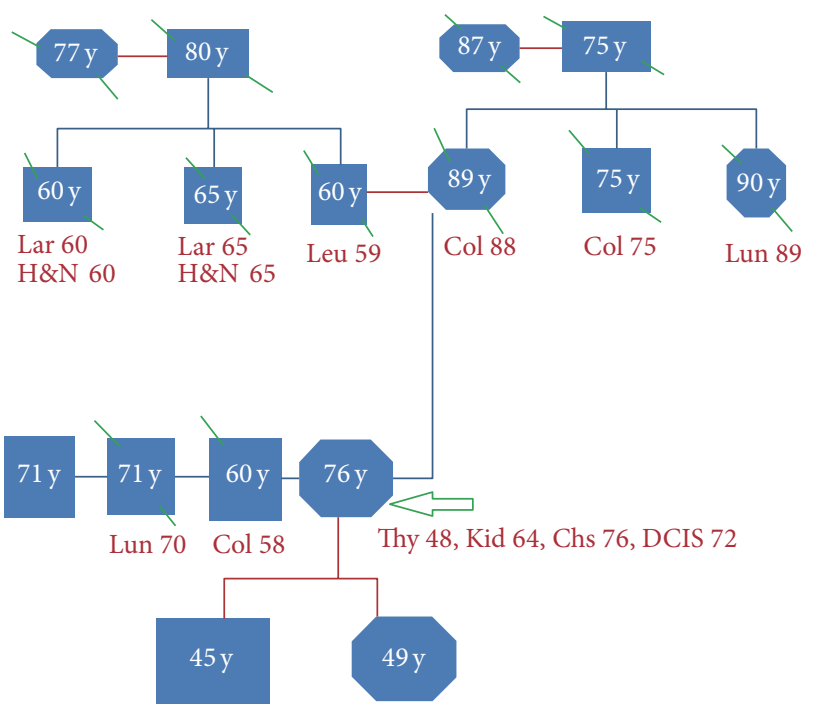

$\begin{array}{lll}\text { Male } & \text { Kid } \text { Kidney cancer } \\ \text { Female } & \text { Lar Throat cancer } \\ \text { Deceased } & \text { Leu Leukemia } \\ \text { Thy } & \text { Thyroid cancer } & \text { Chs Chondrosarcoma } \\ \text { Lun Lung cancer } & \text { Col Colon cancer } \\ \text { H\&N } \text { Mouth cancer } & \text { DCIS Breast ductal carcinoma in situ }\end{array}$

FIGURE 2: A family pedigree of the presenting case showing multiple cancers related to family members. The arrow refers to our presenting case with multiple cancers related to different body systems.

2.9. Molecular Genetics Investigations. Revising the chart of the patient revealed no detectable mutation of the PTEN gene by using denaturing gel gradient electrophoresis analysis. Regarding Li-Fraumeni syndrome, p53 sequencing detected no mutation in the entire coding region of the $\mathrm{p} 53$ gene.

\section{Discussion}

We are reporting a case with multiple cancers which could not fit in any of the reported family cancer syndromes (Table 1). The family history from the mother side is significant for colon, thyroid, lung, kidney, and bladder cancers (Figure 2) in addition to early diagnosis of large villous adenoma with focus of adenocarcinoma in situ at the age of forty-two in our case. The possibility of adenomatous polyposis coli (APC) syndrome is remote in this case because the polyposis is not constituted and no APC gene mutation analysis was performed. Additionally, the multiple cancers diagnosed in the current case look odd to what is published with FAP syndrome. The patient did not develop colon cancer mostly because of careful follow-up and surgical resections of multiple colonic adenomas.

The most common associated cancers published so far with FAP syndrome are colon, ampullary, and duodenal cancers, follicular or papillary thyroid carcinoma, hepatoblastomas in children, gastric cancer, and NS medulloblastomas. Associated benign lesions are colonic, gastric, and duodenal polyps $[2,4,5,7]$, epidermoid and sebaceous cysts, lipomas, osteomas, and desmoid tumors $[16,17]$. In addition to what is in the literature this case had renal cell carcinoma, breast carcinoma, chest wall chondrosarcoma, and ganglioneuroma.

To exclude the possibility of Cowden syndrome associated with breast, thyroid, especially follicular type, colon, and kidney lesions besides many other malignant and benign 
lesions (Table 1), no mutations were detected in the PTEN gene at $10 \mathrm{q} 23$ in our case [8-10]. Additionally, the p53 gene is not mutated to exclude to great extent Li-Fraumeni syndrome which is associated with breast cancer and any other invasive cancer early in life compared to general population with known mutations in the p53 gene at 17p13.1 [18-21].

Table 1 summarizes mode of inheritance and tumors associated with family cancer syndromes with one or more components from the tumor constellation of our case: papillary thyroid carcinoma, renal cell carcinoma, breast carcinoma, chondrosarcoma, colonic adenomas, and ganglioneuroma. So, are we facing a case with constellation of one of the family cancer syndromes listed in the table, just a coincidence, or a new cancer syndrome?

\section{Competing Interests}

The authors declare that there are no competing interests regarding the publication of this paper.

\section{References}

[1] N. M. Lindor and M. H. Greene, "The concise handbook of family cancer syndromes," Journal of the National Cancer Institute, vol. 90, no. 14, pp. 1039-1071, 1998.

[2] S. R. Hamilton, R. E. Parsons, N. Papadopoulos et al., "The molecular basis of Turcot's syndrome," The New England Journal of Medicine, vol. 332, no. 13, pp. 839-847, 1995.

[3] T. Yamaguchi, H. Ishida, H. Ueno et al., "Upper gastrointestinal tumours in Japanese familial adenomatous polyposis patients," Japanese Journal of Clinical Oncology, 2016.

[4] A. M. Lotfi, R. R. Dozois, H. Gordon et al., "Mesenteric fibromatosis complicating familial adenomatous polyposis: predisposing factors and results of treatment," International Journal of Colorectal Disease, vol. 4, no. 1, pp. 30-36, 1989.

[5] P. W. Marcello, H. J. Asbun, M. C. Veidenheimer et al., "Gastroduodenal polyps in familial adenomatous polyposis," Surgical Endoscopy, vol. 10, no. 4, pp. 418-421, 1996.

[6] M. A. Rodriguez-Bigas, C. R. Boland, S. R. Hamilton et al., "A National Cancer Institute Workshop on Hereditary Nonpolyposis Colorectal Cancer Syndrome: meeting highlights and Bethesda guidelines," Journal of the National Cancer Institute, vol. 89, no. 23, pp. 1758-1762, 1997.

[7] F. Paraf, S. Jothy, and E. G. Van Meir, "Brain tumor-polyposis syndrome: two genetic diseases?" Journal of Clinical Oncology, vol. 15, no. 7, pp. 2744-2758, 1997.

[8] D. Liaw, D. J. Marsh, J. Li et al., "Germline mutations of the PTEN gene in Cowden disease, an inherited breast and thyroid cancer syndrome," Nature Genetics, vol. 16, no. 1, pp. 64-67, 1997.

[9] M. R. Nelen, G. W. Padberg, E. A. J. Peeters et al., "Localization of the gene for Cowden disease to chromosome 10q22-23," Nature Genetics, vol. 13, no. 1, pp. 114-116, 1996.

[10] S. Olschwang, O. M. Serova-Sinilnikova, G. M. Lenoir, and G. Thomas, "PTEN germ-line mutations in juvenile polyposis coli," Nature Genetics, vol. 18, no. 1, pp. 12-14, 1998.

[11] M. H. Brownstein, A. H. Mehregan, J. B. Bikowski, A. Lupulescu, and J. C. Patterson, "The dermatopathology of Cowden's syndrome," British Journal of Dermatology, vol. 100, no. 6, pp. 667-673, 1979.
[12] L. Schmidt, F.-M. Duh, F. Chen et al., "Germline and somatic mutations in the tyrosine kinase domain of the MET protooncogene in papillary renal carcinomas," Nature Genetics, vol. 16, no. 1, pp. 68-73, 1997.

[13] H. A. Drabkin, C. Bradley, I. Hart, J. Bleskan, F. P. Li, and D. Patterson, "Translocation of c-myc in the hereditary renal cell carcinoma associated with a $\mathrm{t}(3 ; 8)(\mathrm{p} 14.2 ; \mathrm{q} 24.13)$ chromosomal translocation," Proceedings of the National Academy of Sciences of the United States of America, vol. 82, pp. 6980-6984, 1985.

[14] V. Perrier-Trudova, B. W. Huimin, S. Kongpetch et al., "Fumarate hydratase-deficient cell line NCCFH1 as a new in vitro model of hereditary papillary renal cell carcinoma Type 2," Anticancer Research, vol. 35, no. 12, pp. 6639-6653, 2015.

[15] B. Zbar, G. Glenn, I. Lubensky et al., "Original articles: kidney cancer: hereditary papillary renal cell carcinoma: clinical studies in 10 families," The Journal of Urology, vol. 153, no. 3, pp. 907912, 1995.

[16] D. M. Eccles, R. van der Luijt, C. Breukel et al., "Hereditary desmoid disease due to a frameshift mutation at codon 1924 of the APC gene," The American Journal of Human Genetics, vol. 59, no. 6, pp. 1193-1201, 1996.

[17] S. Klemmer, L. Pascoe, and J. DeCosse, "Occurrence of desmoids in patients with familial adenomatous polyposis of the colon," American Journal of Medical Genetics, vol. 28, no. 2, pp. 385-392, 1987.

[18] J. M. Birch, A. L. Hartley, K. J. Tricker et al., "Prevalence and diversity of constitutional mutations in the p53 gene among 21 Li-Fraumeni families," Cancer Research, vol. 54, no. 5, pp. 1298 1304, 1994.

[19] T. Frebourg, N. Barbier, Y.-X. Yan et al., "Germ-line p53 mutations in 15 families with Li-Fraumeni syndrome," American Journal of Human Genetics, vol. 56, no. 3, pp. 608-615, 1995.

[20] D. Malkin, F. P. Li, L. C. Strong et al., "Germ line p53 mutations in a familial syndrome of breast cancer, sarcomas, and other neoplasms," Science, vol. 250, no. 4985, pp. 1233-1238, 1990.

[21] F. P. Li, J. E. Garber, S. H. Friend et al., "Recommendations on predictive testing for germ line p53 mutations among cancerprone individuals," Journal of the National Cancer Institute, vol. 84, no. 15, pp. 1156-1160, 1992. 


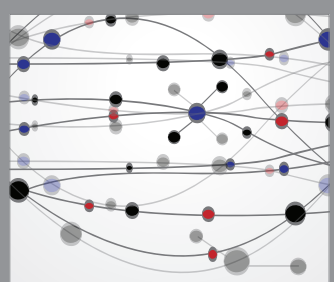

The Scientific World Journal
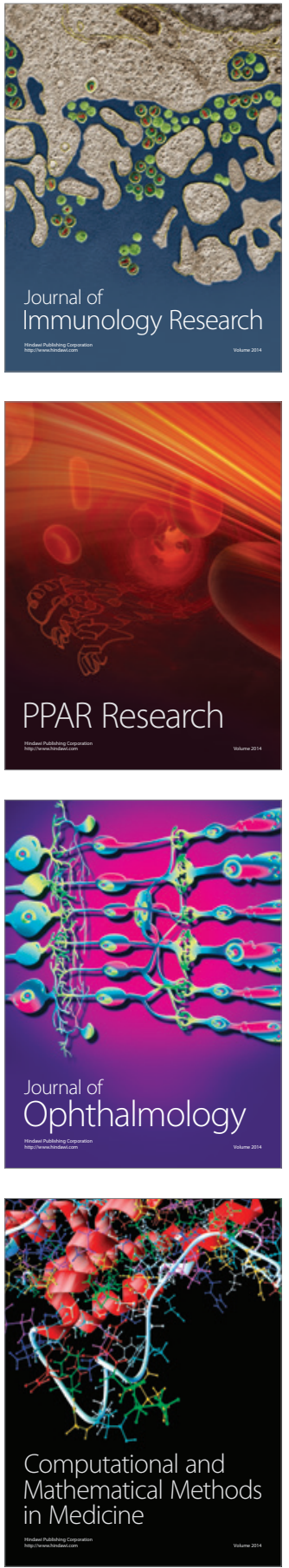

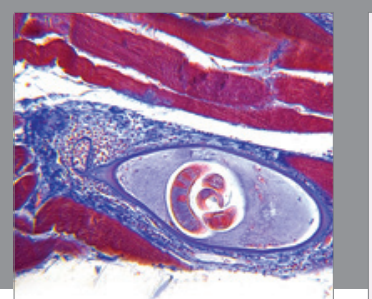

Gastroenterology Research and Practice

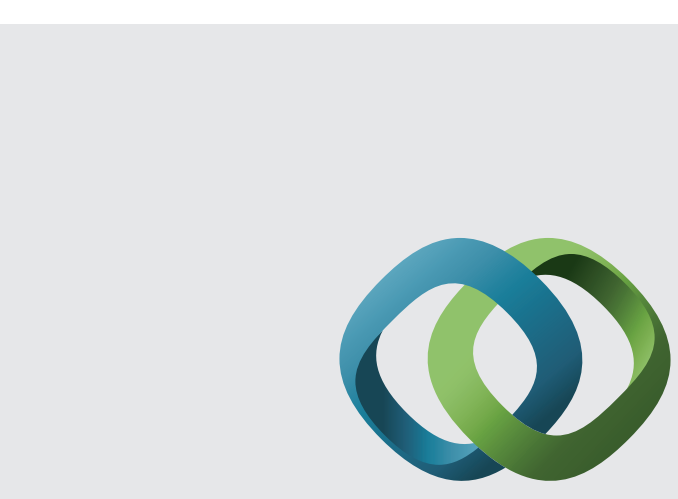

\section{Hindawi}

Submit your manuscripts at

http://www.hindawi.com
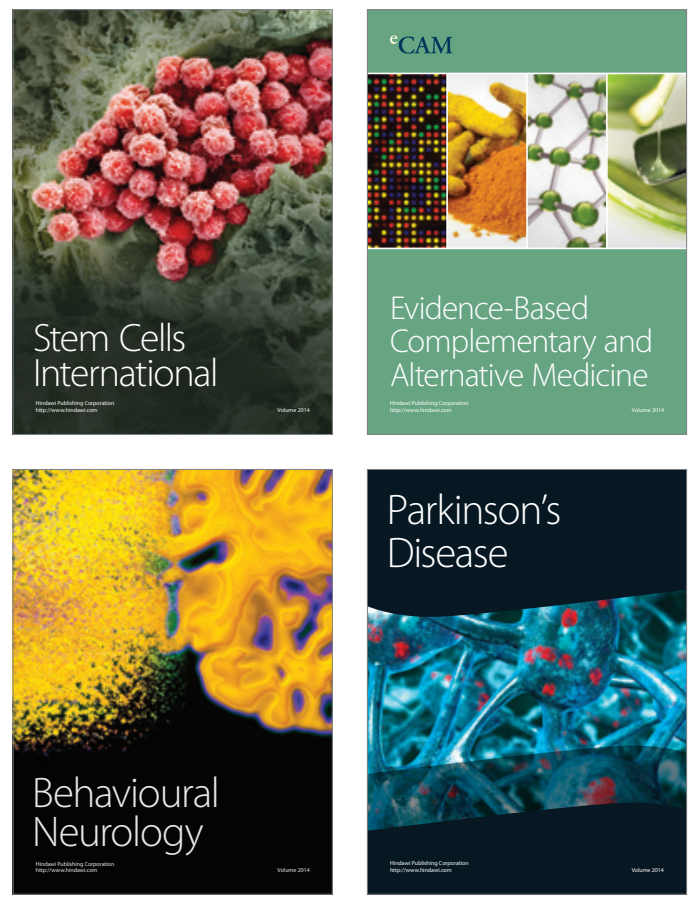
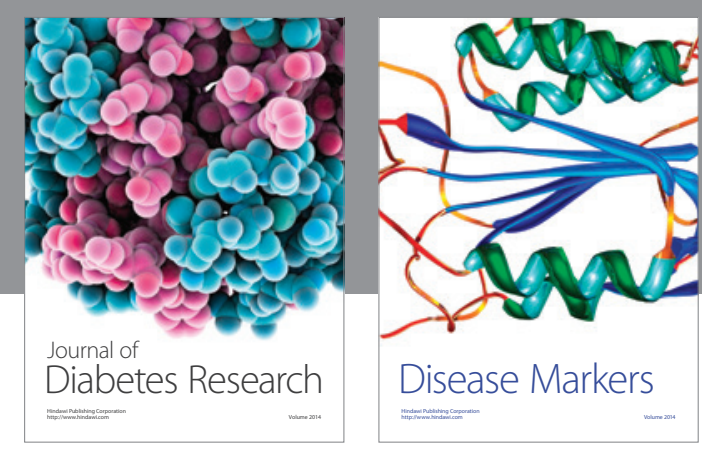

Disease Markers
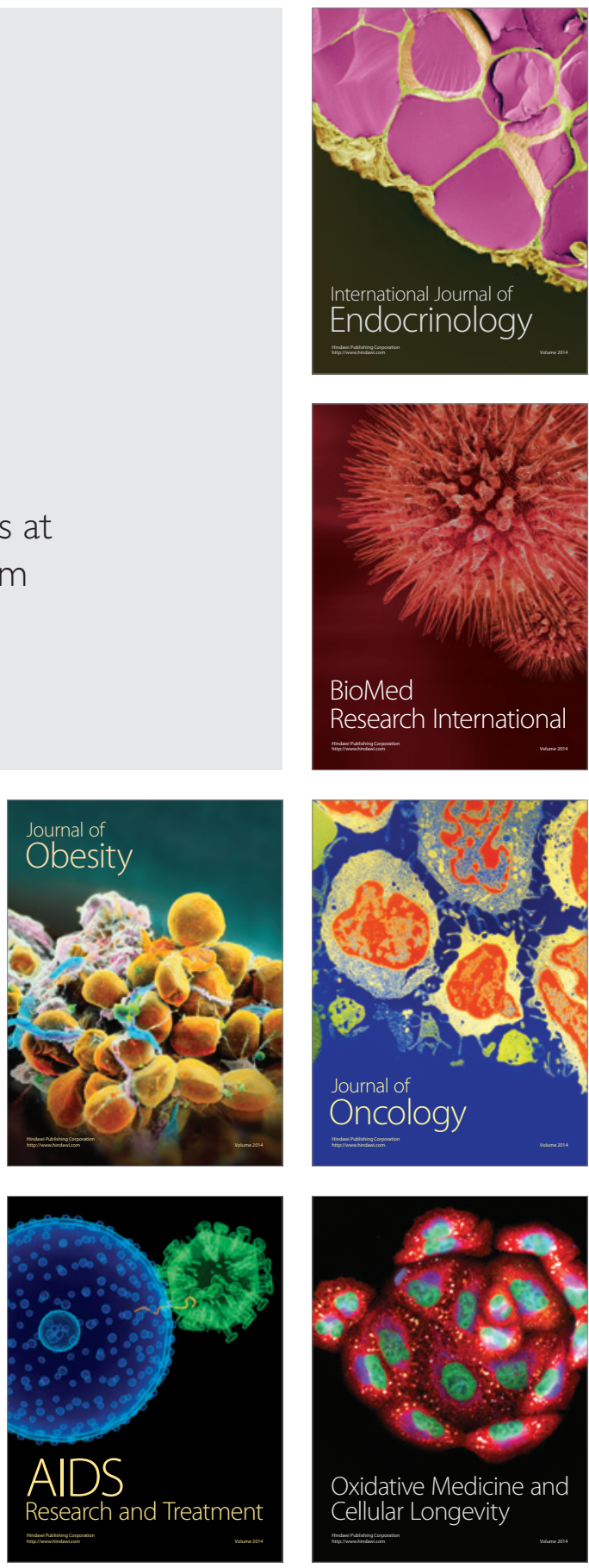